\title{
Life Trajectories of Migrant Care Workers in the Long-Term Care Sectors in Norway and the UK
}

\section{Karen Christensen}

University of Bergen, Norway

E-mail: Karen.Christensen@uib.no

An ageing population in Europe is currently putting pressure on long-term care services, creating demand for foreign workers. Using a life-course perspective, this article aims to contribute to the understanding of how life trajectories shape decisions about migration and employment in social care. Based on fifty-one life story interviews with migrant care workers in Norway and UK, two typologies are found: a Norwegian migrant life trajectory of downwards social mobility combined with settlement and a British trajectory combining stronger downwards social mobility with further migration. The article contributes to the discussion of contextualised migratory lives involving care work.

Keywords: Life trajectories, migrant care workers, Norway and UK, social care, social mobility.

\section{Introduction}

Today, a significant number of European long-term care workers are migrants. In Norway, migrants constitute 13 per cent of the work force (Abrahamsen and Kjelvik, 2013), in the United Kingdom (UK) 19 per cent (Spencer et al., 2010), with much higher numbers in the biggest cities. In both countries, difficulties with recruiting native workers (Hussein et al., 2011; Holmøy et al., 2016) is one reason for the inclusion of foreign workers (Cangiano et al., 2009). Norway and the UK both implemented migration policies, particularly after 2004, that opened the doors for foreign workers from EU/EEA countries, ${ }^{1}$ while restricting entrance for those from outside these countries. Although having some similarities in these European-friendly migration policies (lasting until the UK leaves the EU following the referendum in 2016), the two countries provide different contexts. Unlike Norway, the UK has a colonial history, its labour market is characterised by insecurity and little regulation, and in terms of welfare regimes (Esping-Andersen, 1999), the UK represents a liberal type. In contrast, Norway's regime is based on the Nordic social democratic model, implying that the Norwegian population's welfare is less dependent on the family and a private market, the state having the main responsibility. In general and as part of welfare policies, Norway also more strongly emphasises gender equality in society.

This article is inspired by a life-course approach rooted in the classic sociological idea of a relationship between biography and history: understanding people's lives as created actively by individuals encountering certain conditions and options at specific historical times and places (Mills, 1959). Based on life story interviews, its purpose is to discuss life trajectories involving migration and care work. It explores three dimensions: the motivation for going abroad, the social mobility direction and 'scale' of this through 
entry into care work and the choice of whether to settle or not in the host country. Until recently, the life-course approach has been limited in migration research (Wingens et al., 2011) and this is still mostly the case in literature about migration and care. This article therefore also contributes to filling this gap. In the following, I will place the data and methods that this article draws on in the literature's discussions of care work and migration and finally explore two typologies of migrant life trajectories. There are three discussions that this article will contribute to: one related to the concept of 'Global care chains' (Hochschild, 2000), another related to migrant lives in European countries regarding settlement or fluid migration trajectories, and a third related to the interrelation of long-term care policies and care work arrangements for migrants.

\section{Global care and migratory lives of care workers}

Worldwide, the female share of people leaving their home country temporarily or permanently is increasing, particularly in Europe (United Nations, 2016). Related to care work and domestic work, much attention has been paid to this feminisation of migration through the lens of a global care chains perspective, discussing how chains between women are developed in a geopolitically unequal way when women from the South leave their children and family behind to earn money in the global North in middle-class families, while replacing their care work back home with other (lower paid) migrant women. However, while this discussion emphasises an important process of commodification of reproductive work, domestic work and childcare, it 'tends to generalise from only one type of migration and care situation when the reality is more diverse' (Williams, 2010: 387; see also Bauer and Österle, 2013) and it also tends to present migrant women as victims without agency (Yeates, 2009: 7). This article is a contribution to a 'more diverse' understanding of migration and care as it explores the agency of migrants engaged in care work for older and disabled people.

Contrasting earlier once-in-a-lifetime-movement, migration today is characterised by more mobility, sometimes in terms of 'circular migration' between two countries (Parreñas, 2010); more mobility is even seen as mirroring modern 'liquid' life (Bauman, 2000). Related to this mobile life, the concept of 'transnationalism' (Levitt and Schiller, 2004) was developed in order to conceptualise how relationships and identities can be maintained across national borders. Since then, the idea of liquid and transnational lives has been questioned, highlighting for example, that liquid migration provides a European context which still leaves space for developing 'grounded lives' in terms of settlement, security and stability (Bygnes and Erdal, 2017). The concept of 'mobility-enclosure', that is contradictions and tensions related to life in a foreign country, such as, for example, being ambivalent about one's home country but feeling frustrated about not being integrated into the host country has also been proposed (O'Reilly, 2007). The article will make an empirically based contribution to this discussion of settlement and integration, while focusing on social mobility.

A third discussion concerns the circumstances of migrants within the long-term care sector. The literature has revealed the role of personalisation policies, giving welfare users more choice and control over their services, as a central policy response to the ageing population in Europe (Christensen and Pilling, 2014). These policies imply a shift in the role of service users from being passive receivers of traditional social care to becoming active independent citizens who influence their services, including receiving cash to 
employ their own workers, typically called personal assistants, to differentiate them from 'care' workers. Both Norway and the UK have implemented personalisation policies. In the UK (mainly England), there is greater variation of cash-for-care arrangements (Baxter et al., 2010): the care recipient either uses the allocated budget for social care to employ care workers directly or through a provider organisation, many of which are for-profit, or chooses to have the local authority manage it for them, or a combination of these options. Additionally, there are self-funders in the market, paying out of their own pockets. This is related to the UK means-tested allocation of social care. These policies have increased the variety of arrangements of care work in private households, including live-in arrangements in the UK, the care worker living in the user's home. Related to these circumstances, in particular in the UK, attention has been paid to, for example, risks related to intimate relationships and an insecure labour market (Christensen and Manthorpe, 2016), the weakening of care workers' employee role when users are empowered (Guldvik et al., 2014), including problems with getting qualifications from the home country recognised (Datta et al., 2007) and gendered ways of perceiving female-dominated care work (Lupton, 2000; Hussein and Christensen, 2016). In contrast, the allocation of social care in Norway is needs-tested and mainly undertaken on a non-profit basis; and care workers do not live with their employers. The discussion here will contribute to the literature by exploring these issues through a migrant life course perspective (Elder, 1994).

\section{Data and method}

The article's data are based on a comparative study into the lives of migrant care workers in Norway and the UK (Christensen and Guldvik, 2014). ${ }^{2}$ Criteria for the selection of participants were that they should be: adults, women or men, born outside Norway or the UK, have left their home country as adults to be able to reflect on transnational experiences, and have experiences with home-based care work in Norway or the UK, in particular personal assistance work for disabled or older people. As home-based care work is public, but takes place in people's private homes, and the employment of care workers is personalised, to various extents outside public control, the recruitment process was like finding a 'hidden group of workers' (ibid.: 29). Therefore, multiple recruitment strategies were used, the most important in Norway being through gate openers willing to find migrants in their user support organisations, and in the UK accessing websites used by care workers to find a job.

The empirical material was developed through life story interviews, carried out as semi-structured interviews with an interview guide covering background in the home country, decision-making processes about going abroad, experiences of migrating to Norway or the UK, undertaking long-term care work, and future plans. The interviews usually lasted for ninety minutes and took place primarily in cafés in London and Norwegian cities, these providing good environments for telling one's story over a cup of coffee. Trust in the researcher-interviewee relationship was essential. While all the interviews in the UK were carried out in English, the ones in Norway were primarily carried out in Norwegian, and a few times in English if the participant found the Norwegian language challenging.

More interviews were conducted in the UK (cf. Table 1) to compensate for the two researchers' Scandinavian background. These were undertaken in 2011-13. Reflecting the gendered nature of care work, the majority of participants were women. 
Table 1 Overview of the 51 interviewees

\begin{tabular}{|c|c|c|}
\hline & Norway: 20 & UK: 31 \\
\hline Gender & 12 women, 8 men & 22 women, 9 men \\
\hline Age at time of interview & $25-49$ & $19-59$ \\
\hline Class background & $\begin{array}{l}\text { Most middle class: } 12 \\
\text { women and } 4 \text { men }\end{array}$ & $\begin{array}{l}\text { Most middle class: } 16 \\
\text { women and } 7 \text { men }\end{array}$ \\
\hline $\begin{array}{l}\text { Relationship status when } \\
\text { entering N/UK first time }\end{array}$ & Most single: $12(60 \%)$ & Most single: $19(61 \%)$ \\
\hline Years in N/UK & $1-28$ & $0.2-20$ \\
\hline Home country & $\begin{array}{l}\text { Including Germany, } \\
\text { Switzerland, Poland, } \\
\text { Hungary, Romania, } \\
\text { Lithuania; and Argentina, } \\
\text { Ethiopia, Thailand, } \\
\text { Philippines, Iran, Russia }\end{array}$ & $\begin{array}{l}\text { Including Poland, Spain, } \\
\text { Hungary, Bulgaria, } \\
\text { Slovakia, Latvia, Portugal; } \\
\text { and South Africa, Nigeria, } \\
\text { Uganda, Zimbabwe, India }\end{array}$ \\
\hline $\begin{array}{l}\text { Personal assistance } \\
\text { experiences }\end{array}$ & $\begin{array}{l}\text { 20; nobody had live-in } \\
\text { experiences }\end{array}$ & $\begin{array}{l}\text { 28; } 15 \text { had live-in } \\
\text { experiences }\end{array}$ \\
\hline
\end{tabular}

\section{The Norwegian migrant life trajectory}

The data from Norway revealed that participants often did not consciously choose to go to this, often unknown, country. Rather, they moved there as asylum-seekers fleeing from war in their home country or due to strong personal relationships, as Elena's case demonstrates. Elena, twenty-seven years old at the time of the interview, grew up in Lithuania in a middle-class family like the other female interviewees and half of the male interviewees. At age twenty-two, she decided to go to Norway for a short period of study as part of her bachelor's degree in physiotherapy. While she was there, she met a German man and stayed in contact with him after they both left Norway. When he returned to Norway, Elena visited him and the relationship developed, culminating in a long-term commitment. After finishing her Master's degree in physiotherapy, she returned to Norway and decided to stay with him. When Lithuania joined the EU in 2004, she could, like her partner whom she later married, enter Norway freely.

Similar to many of the interviewees in Norway, her master's degree was not recognised and her Norwegian was not advanced enough for a professional job. She therefore, at some point, went into (low-paid) care work as a personal assistant, full-time work for a disabled person normally being shared between three workers, thereby avoiding very intimate relationships (Guldvik et al., 2014). Like most of the other female interviewees, Elena used care work as a stepping stone into the labour market, but the path to qualified work had a high price. Unlike refugees, who were allowed to stay in Norway for humanitarian reasons and through this role got access to Norwegian language courses (Brochmann and Hagelund, 2010), Elena had no such access except by paying herself for these. Accepting the non-recognition of her qualifications from Lithuania, she decided to do another postgraduate course which involved a further two years of education in Norway.

Of the twelve female migrants interviewed in Norway, ten held a bachelor or a master's degree when they came to Norway, therefore having high expectations of getting a qualified job. However, non-recognition of their qualifications, and language problems 
were common factors which contributed to a period of deskilling (Datta et al., 2007), that is, taking on a job that does not match one's achieved cultural capital:

I understand that I have to start at a low level, first and foremost because of the language. Therefore, I started at a home for elderly people. I have applied for many jobs since I came here. I need some work practice to show in my CV that I have worked in my professional field. (Elena, 27, Lithuania)

As a care-worker, here in a home for elderly people, Elena clearly experienced downwards social mobility. Experiences of deskilling revealed a gendered dimension. For male migrants, particularly those with working-class backgrounds, care work was associated with 'women's work' (Hussein and Christensen, 2016), in terms of its associations with the three Cs - cooking, cleaning and caring (Anderson, 2000) - and in terms of the work's characteristics such as being part-time, low-paid and with low social status (Guldvik et al., 2014; see also England, 2005). While the male care workers with middle-class backgrounds were dissatisfied with their working conditions, those with working-class backgrounds did not have aspirations for a professional career, and therefore found it easier to find satisfaction in their work, as in the case of Alvar:

I am the companion, and I am fixing things ... For the most I help him [the disabled man he is working for]. If he is swimming, I swim behind him. So it is training for me too. And I am responsible for cooking. I like cooking ... Then we can do things together which are more fun, such as training. It is like friendship, isn't it? But he shall always decide. (Alvar, 30, Argentina)

With no professional career ambitions, Alvar enjoyed the relationship with the person he was caring for and doing what he wanted. He represents the study's working-class men with non-masculine attitudes, such as enjoying household tasks, thereby moving into non-traditional gender roles (Lupton, 2000; Hussein and Christensen, 2016). These men entered the relationship with the user as stronger autonomists than women care workers, leading more easily to a relationship of companionship and equality. In this way, and opposed to those with a middle-class background, they combined a new masculine role, doing 'women's work', with traditional masculine values such as avoiding status-drop and relationships that were too intimate.

Regarding the interviewees' future, as seen from the perspective of their life situation at the time of the interview, the typical plan was settlement in Norway. Beside the investment in learning the Norwegian language, a non-transferable form of capital (Christensen et al., 2016), an important settlement reason, supported by using care work as a stepping stone into the labour market, was related to the security of a comprehensive welfare state. In the case of Elena, this became clear after she had married the German man, bought a house in the countryside and had a baby. Having been employed for the last six months before childbirth, she was entitled to the generous Norwegian maternity leave, typically paid and lasting ten to twelve months. She could also explore further labour market connections in the future; Norway's declared intention being provision of full kindergarten cover to enable both fathers and mothers to combine full-time work and childcare, an important step towards gender equality. Similar to other studies (Bygnes and Erdal, 2017), these secure and stable life surroundings emerged as reasons for settlement and 'grounded' lives in Norway. 
However, settlement was not unproblematic. Demonstrating O'Reilly's concept of 'mobility-enclosure', the migrants chose not to go back but did not feel well integrated in their local surroundings, including workplaces:

after two months they [the other employees] asked me where I actually came from ... they heard immediately that I was not Norwegian. I said 'Switzerland'. 'Ahh Switzerland, interesting. Okay and how are you here?' 'I'm fine."'Ahh, okay yeah.' And that was it. No interaction. Nothing ... my husband said ... this is how it is, and they don't mean it'. (Lena, 32, Switzerland)

\section{The British migrant life trajectory}

In contrast to Norway, the UK was typically chosen directly, as shown by the case of Brenda. Brenda, twenty-eight years old at the time of the interview, grew up, as one of six children, in a middle-class family, like the majority of the UK-based interviewees. However, she experienced challenging surroundings in Uganda during her childhood, including floods and droughts resulting in food shortages, and witnessing children's loss of their parents due to HIV. Uganda is a former British colony, and although it became independent in 1962, the British school system has remained in the country and English is taught as a second language. Therefore, when Brenda first decided to go to the UK at the age of twenty-three, this was related to the country's historical connection to the British former empire. She became a Christian and started working for Christian organisations, which recruited members for volunteering in the UK. On returning to her home country, Brenda finished a bachelor degree in tourism, but encountering difficulties with finding work she returned to the UK. This time, as a non-European person with restricted access, she obtained a six months' visitor's visa allowing her to stay for this period, but not allowing her to work. However, as care work lies in-between the boundaries of public and private spheres, particularly when taking place in private households with the care user as the employer, she became an illegal worker in private homes in a 'grey' care market. It was through a weak tie in her informal church network, becoming 'strong' (Ryan, 2016) in terms of helping her to find a job, that she entered care work. She felt that she was not taking this work from British people, as she knew that many British workers are not attracted to this type of work (Hussein et al., 2011; Christensen et al., 2016). However, towards the end of this period she struggled a lot, almost living on the streets of London, and eventually returned to Uganda. When she came to the UK for the third time - before July 2012 when restrictions were imposed on family migration which impacted on UK citizens who wished to sponsor a spouse from outside the EU - she was able to enter the country as she had married a Polish man with British citizenship and therefore was now allowed access as the wife of a British citizen.

Another main motivation for going to the UK was to travel. This was particularly strong among those from former East-European communist societies who had not been allowed to go abroad before their country obtained independence. The UK's international status and the widespread use of English were powerful 'pull' factors. Migration to the country presented no access problems for European people (as long as the UK was in the EU), but for those outside the EU, like Brenda, it was dependent on meeting national access criteria. 
Entering care work soon after arrival, was experienced as easy (Hussein et al., 2011: 290):

I had only moved in from another country ... So the easiest job you could get hold of is care work and quite a few jobs. (Brenda, 27, Uganda)

However, this was experienced as strong downwards social mobility. It was not only related to a middle-class background, with three of the UK participants holding a master's degree and two-thirds of them having a professional occupational background, but very much mixed with experiences of being discriminated against:

it was a bit of a shock to me ... to realise that I was treated differently. That suddenly nobody is interested in my background or my abilities or my skills, my education. That I'm just a pair of hands that should be used in the most effective way. (Michaela, 30, Slovakia)

Michaela's statement represents the emotional challenges related to live-in care arrangements found among many of the UK-based interviewees in this and other studies (e.g. Bauer and Österle, 2013). Citing an example of this, she recalled that when she was hired in the role of an au pair (normally hired for domestic work and childcare) for a disabled woman with muscle disease making her dependent on 24/7 care, she entered into a hierarchy of care workers in the home that the disabled woman shared with her younger husband. At the top of the hierarchy was a care worker called 'a foreign student' (a Korean girl), the next was a British personal assistant, and at the bottom was, as she said, 'always a girl from East Europe, an "au pair"'. The case shows the almost unlimited options for designing care work in private households (cf. also Williams, 2010) and the risks related to intimate live-in arrangements (Christensen and Manthorpe, 2016). Experiences of discrimination also emerged as gendered; male care workers felt discriminated against in gaining entry into feminised social care work (Hussein and Christensen, 2016)

No dominant settlement tradition was found in the life trajectory typology of the UK participants. Rather, further migration, sometimes 'circular', was common (Parreñas, 2010). Brenda's case illustrates the transnational decision of whether to stay or move back. While she decided to undertake further qualifications to improve her position within the social care labour market in the UK, she also had plans, together with her Polish husband, to move back, help her country and experience more respect in old age in Uganda:

I will still have ... that connection with my country ... I've got much more to give ... helping Uganda as a country ... It's something you wouldn't have here ... the old people get respected ... people adore them. (Brenda, 27, Uganda)

But again a contradictory situation was found here (O'Reilly, 2007), in terms, for example, of gaining British citizenship for pragmatic reasons, but still feeling a sense of belonging to one's home country. Most of them planned to move back later in life:

it's just the system of the world ... because [if] you live in Britain, you need to work ... [but] work is for British [people] ... so it's ok to be British as long as you are in Britain. (Hazel, 50, Zimbabwe) 


\section{Conclusion}

The study reveals two contrasting, empirically based life trajectories. With its weak historical connection to the rest of the world and the necessary investment in learning a language not transferable to other countries, Norway rarely appears as a choice of destination. In contrast, migrants to the UK were strongly attracted to the international status of the country and the language but further or circular migration was indicated. Both country-cases revealed objective factors as well as subjective feelings of downwards social mobility due to the dominating middle-class backgrounds of the migrant participants and their entry into the long-term care sector. These trajectories were based on the migrants' active way of encountering country-specific circumstances, and related to historical crosscountry relationships. However, the phenomenon emerged more strongly in the UK due to the way the personalisation policies have weakened the role of the state and moved much responsibility into private households, encouraging live-in arrangements, and putting pressure on the working conditions. The difference in type of welfare regime is also an important context-explanation as to why settlement is the preferred end of the life trajectory in Norway, while further migration is clearly stronger among the UK participants: Norway's welfare regime can contribute to creating a stable life situation; the country also offers more secure working conditions and generous welfare arrangements. Important contradictions in migratory lives remain to be explained and further explored, including, for example, the tension between aspirations for settlement and integration difficulties in Norway, and acquiring British citizenship but feeling a sense of belonging to the home country.

The article contributes to three migration-and-care discussions in the literature. It widens the lens of the global care chains perspective. While this perspective typically stresses feminised migration related to domestic work and childcare and a South-North inequality issue, this study instead points at the pressure on social care due to the demographic challenge of an ageing population in Europe and how this increasingly brings migrant women as well as migrant men, from countries outside and inside Europe, into care work, here for older and disabled people. Using a life course approach, the study also reveals migration as a creatively developed part of individual life projects, although involving various forms of downwards social mobility related to entering care work. The article then, secondly, also contributes to the discussion of 'liquid' lives due to increasing migration. Here, it brings in a differentiation by comparing and discussing how different European country contexts represent different conditions and options, which migrants actively respond to. This discussion shows that some contexts encourage 'liquid lives' or further mobility while others discourage them. The third contribution concerns the policies of personalisation, strongly influencing social care policies in many European countries, and in Norway and the UK creating very different ways of organising social care work in people's homes. This part provides insight into how migrants contribute to supporting independent lives for older and disabled people, but simultaneously encounter risks related to the stronger versions of 'personalisation', when including very intimate situations and subordinated relationships to the user. However, this mainly easily accessible care work can also provide a stepping-stone into the labour market and in the future even create more circumstances for developing new gender roles and work that loses the ties to women's work and its low-status associations. 


\section{Notes}

1 Norway never became an EU member, unlike the UK, but joined the European Free Trade Association (EFTA), and when the European Economic Area (EEA) was established, both EU member states and EFTA countries were included. In 2004 and 2007, the EU was enlarged with new member states.

2 The data from UK are also used in: Christensen and Manthorpe, 2016; and Hussein and Christensen, 2016. The data from Norway in: Christensen, Hussein and Ismail, 2016.

\section{References}

Abrahamsen, D. R. and Kjelvik, J. (2013) 'Dobling av innvandrerårsverk på fem år', in J. Ramm (ed.), Eldres bruk av helse- og omsorgstjenester, Oslo-Kongsvinger: Statistics Norway, 55-61.

Anderson, B. (2000) Doing the Dirty Work: The Global Politics of Domestic Labour, London and New York: Zed Books.

Bauer, G. and Österle, A. (2013) 'Migrant care labour: the commodification and redistribution of care and emotional work', Social Policy and Society, 12, 3, 461-73.

Bauman, Z. (2000) Liquid Modernity, Cambridge: Polity Press.

Baxter, K., Wilberforce, M. and Glendinning, C. (2010) 'Personal budgets and the workfore implications for social care providers: expectations and early experiences', Social Policy and Society, 10, 1, 55-65.

Brochmann, G. and Hagelund, A. (2010) Velferdens Grenser, Oslo: Universitetsforlaget.

Bygnes, S. and Erdal, M. B. (2017) 'Liquid migration, grounded lives: considerations about future mobility and settlement among Polish and Spanish migrants in Norway', Journal of Ethnic and Migration Studies, 43, 1, 102-18.

Cangiano, A., Shutes, I., Spencer, S. and Leeson, G. (2009) Migrant Care Workers in Ageing Societies: Research Findings in the United Kingdom, Compas. Oxford: University of Oxford.

Christensen, K. and Guldvik, I. (2014) Migrant Care Workers: Searching for New Horizons, Surrey: Ashgate.

Christensen, K., Hussein, S. and Ismail, M. (2016) 'Migrants' decision-process shaping work destination choice: the case of long-term care work in the United Kingdom and Norway', European Journal of Ageing, http://link.springer.com/article/10.1007/s10433-016-0405-0 [accessed 07.01.2017].

Christensen, K. and Manthorpe, J. (2016) 'Personalised risk: new risk encounters facing migrant care workers', Health, Risk and Society, 18, 3-4, 137-52.

Christensen, K. and Pilling, D. (2014) 'Policies of personalisation in Norway and England: on the impact of political context', Journal of Social Policy, 43, 3, 479-96.

Datta, K., Mcllwaine, C., Evans, Y., Herbert, J., May, J. and Wills, J. (2007) 'From coping strategies to tactics: London's low-pay economy and migrant labour', British Journal of Industrial Relations, 45, 2, 404-32.

Elder, G. H. (1994) 'Time, human agency, and social change: perspectives on the life course', Social Psychology Quarterly, 57, 1, 4-15.

England, P. (2005) 'Emerging theories of care work', Annual Review of Sociology, 1, 1, 381-99.

Esping-Andersen, G. (1999) Social Foundations of Post-industrial Economies, Oxford: Oxford University Press.

Guldvik, I., Christensen, K. and Larsson, M. (2014) 'Towards solidarity: working relations in personal assistance', Scandinavian Journal of Disability Research, 16, S1, 48-61.

Hochschild, A. R. (2000) 'Global care chains and emotional surplus value', in W. Hutton and A. Giddens (eds.), Global Capitalism, New York: The New Press, 130-46.

Holmøy, E., Haugstveit, F. V. and Otnes, B. (2016) 'Behovet for arbeidskraft og omsorgsboliger i pleie- og omsorgssektoren mot 2060', Report 20/2016, Oslo-Kongsvinger: Statistics Norway.

Hussein, S. and Christensen, K. (2016) 'Migration, gender and low-paid work: on migrant men's entry dynamics into the feminised social care work in the UK', Journal of Ethnic and Migration Studies, 43, 5, 749-65. 
Hussein, S., Stevens, M. and Manthorpe, J. (2011) 'What drives the recruitment of migrant workers to work in social care in England?', Social Policy and Society, 10, 3, 285-98.

Levitt, P. and Glick Schiller, N. (2004) 'Conceptualizing simultaneity: a transnational social field perspective on society', The International Migration Review, 38, 3, 1002-39.

Lupton, B. (2000) 'Maintaining masculinity: men who do "women's work"', British Journal of Management, 11 (special issue), S33-S48.

Mills, C. W. (1959) The Sociological Imagination, New York: Oxford University Press.

O'Reilly, K. (2007) 'Intra-European migration and the mobility-enclosure dialectic', Sociology, 41, 2, 277-93.

Parreñas, R. S. (2010) 'Homeward bound: the circular migration of entertainers between Japan and the Philippines', Global Networks, 10, 3, 301-23.

Ryan, L. (2016) 'Looking for weak ties: using a mixed methods approach to capture elusive connections', The Sociological Review, 64, 951-69.

Spencer, S., Martin, S., Bourgeault, I. L. and O'Shea, E. (2010) The Role of Migrant Care Workers in Ageing Societies: Report on Research Findings in the United Kingdom, Ireland, Canada and the United States, No. 41, Oxford: International Organization for Migration.

United Nations (2016) International Migration Report 2015: Highlights, New York: United Nations.

Williams, F. (2010) 'Migration and care: themes, concepts and challenges', Social Policy and Society, 9, 3, 385-96.

Wingens, M., Windzio, M., de Valk, H. and Aybek, C. (2011) A Life-Course Perspective on Migration and Integration, London: Springer.

Yeates, N. (2009) Globalizing Care Economies and Migrant Workers: Explorations in Global Care Chains, New York: Palgrave Macmillan. 